\title{
Amblyomma aureolatum (Acari: Ixodidae) parasitizing margay (Leopardus wiedii) in Rio Grande do Sul
}

\author{
Amblyomma aureolatum (Acari: Ixodidae) parasitando Gato-Maracajá \\ (Leopardus wiedii) no Rio Grande do Sul
}

João Ricardo Martins ${ }^{1 *}$; José Reck Jr. ${ }^{2}$; Rovaina Laureano Doyle ${ }^{1}$; Nadine Louise Nicolau da Cruz ${ }^{3}$; Anelise Webster de Moura Vieira ${ }^{3}$; Ugo Araújo Souza ${ }^{3}$

${ }^{1}$ Instituto de Pesquisas Veterinárias Desidério Finamor/FEPAGRO

${ }^{2}$ Centro de Biotecnologia, Universidade Federal do Rio Grande do Sul - UFRGS, CAPES fellowship

${ }^{3}$ Faculdade Educacional Jayme de Altavila - FEJAL, CNPq fellowship

Received January 26, 2010

Accepted March 11, 2010

\begin{abstract}
We report the finding of Amblyomma aureolatum (Acari: Ixodidae) parasitizing margay (Leopardus wiedii) in the locality of Gravataí ( $29^{\circ} 47^{\prime} 12.9^{\prime \prime} \mathrm{S}$ and 50 53’ 44.1” W; $241 \mathrm{~m}$ alt.), State of Rio Grande do Sul, Southern Brazil. This is the first report of this species of Ixodidae on margay in Southern Brazil. This finding indicates an increased number of hosts for this tick species.
\end{abstract}

Keywords: Amblyomma aureolatum, ixodidae, margay, Leopardus wiedii, Rio Grande do Sul.

\section{Resumo}

Foi registrado o encontro de Amblyomma aureolatum (Acari: Ixodidae) em gato-maracajá (Leopardus wiedii), na

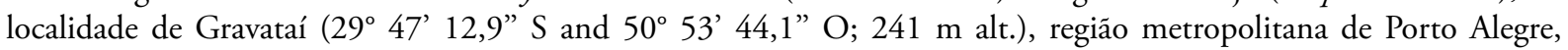
Rio Grande do Sul. Esse é o primeiro registro desse ixodídeo parasitando essa espécie de felídeo e amplia a distribuição de hospedeiros no estado.

Palavras-chave: Amblyomma aureolatum, ixodídeo, gato-maracajá, Leopardus wiedii, Rio Grande do Sul.

\section{Introduction}

Amblyomma aureolatum tick belongs to ixodidae family (Pallas, 1772 ) and its distribution is limited to Neotropical region. Adult ticks are usually found parasitizing carnivores, namely dogs (EVANS et al., 2000; GUGLIELMONE et al., 2003). Aragão and Fonseca (1961b) re-described $A$. aureolatum, which together with Amblyomma ovale Koch, 1844, comprises the ovale complex, validating both taxa in substitution for the names Amblyomma striatum Koch, 1844 and Amblyomma fossum Neumann, 1899. Even though they are synonymous, $A$. aureolatum and $A$. striatum were listed as valid by Barker and Murrell (2004), whereas Guglielmone et al. (2009) invalidated the name A. striatum.

In the records of $A$. aureolatum in wild felids in Brazil, Aragão and Fonseca (1961a) reported finding adults in Leopardus wiedii (margay), Leopardus sp., and Puma concolor (mountain lion), however the collection location of the ixodidae was not specified,

\footnotetext{
${ }^{*}$ Corresponding author: João Ricardo Martins

Instituto de Pesquisas Veterinárias Desidério Finamor/FEPAGRO,

Estrada do Conde, 6000, CEP 92990-000, Eldorado do Sul - RS, Brazil;

e-mail: joaorsm@terra.com.br
}

while Labruna et al. (2005) registered A. aureolatum in Herpailurus yagouaroundi (jaguarundi) in the States of Paraná and São Paulo. In tick samples from the north of Pará State, Aragão and Fonseca (1961a) found A. ovale in P. concolor and Panthera onca (jaguar). A. ovale was also found in L. wiedii in Macapá, Amapá. The presence of $A$. aureolatum in $P$. concolor has been described in three records of different locations in the State of Sáo Paulo (LABRUNA et al., 2005). There are no records of $A$. aureolatum in $L$. wiedii in the State of Rio Grande do Sul.

The margay is a species extremely well adapted to arboreal life, and thus is considered a scansorial animal (FONSECA et al., 1996). Margays feed on small mammals, birds, reptiles, and some insects. They are nocturnal, and solitary. Males usually occupy a territory of approximately $10 \mathrm{~km}^{2}$. Margay is widely distributed on Latin America, being found since Mexico coastal plain to Uruguay. In Rio Grande do Sul State (Brazil) margay can be found in almost entire territory, with the exception of "Campanha" region and littoral zone. Leopardus wiedii is currently considered to be an endangered species under risk of extinction in several regions of Brazil (INDRUSIAK; EIZIRIK, 2003). 


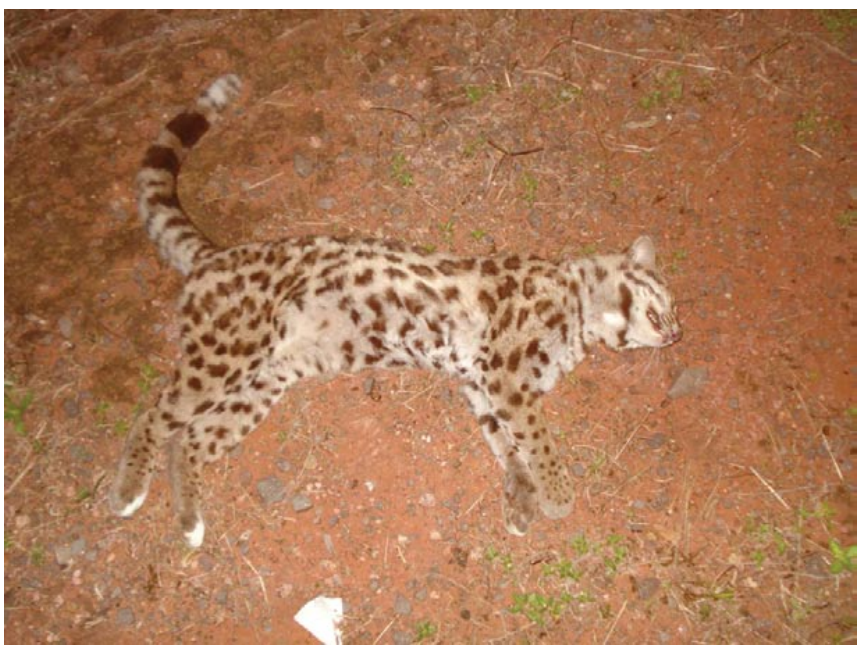

Figure 1. Margay (Leopardus wiedii) found on the RS 020 road, Gravataí, RS.

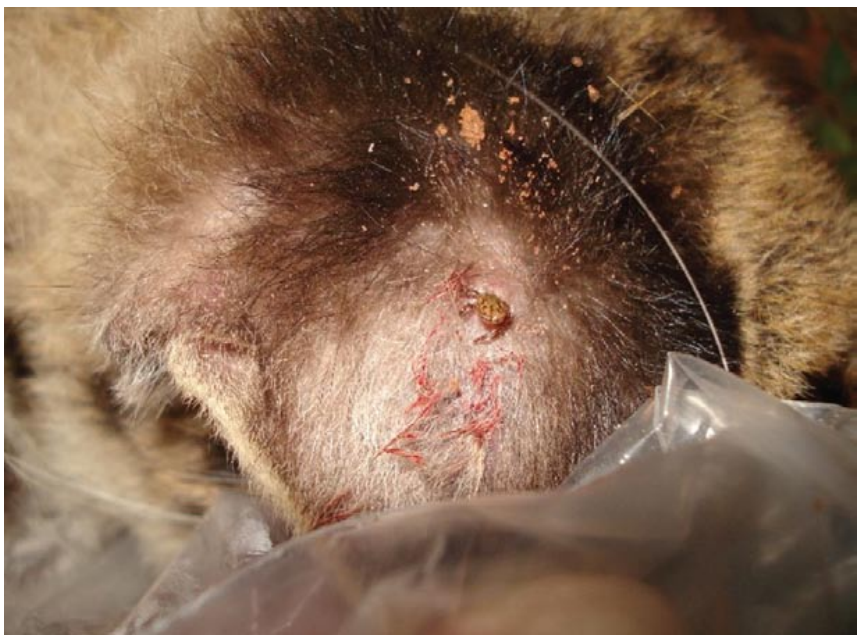

Figure 2. Specimen of $A$. aureolatum found attached on the external side of the ear of a margay, in Gravataí, RS.

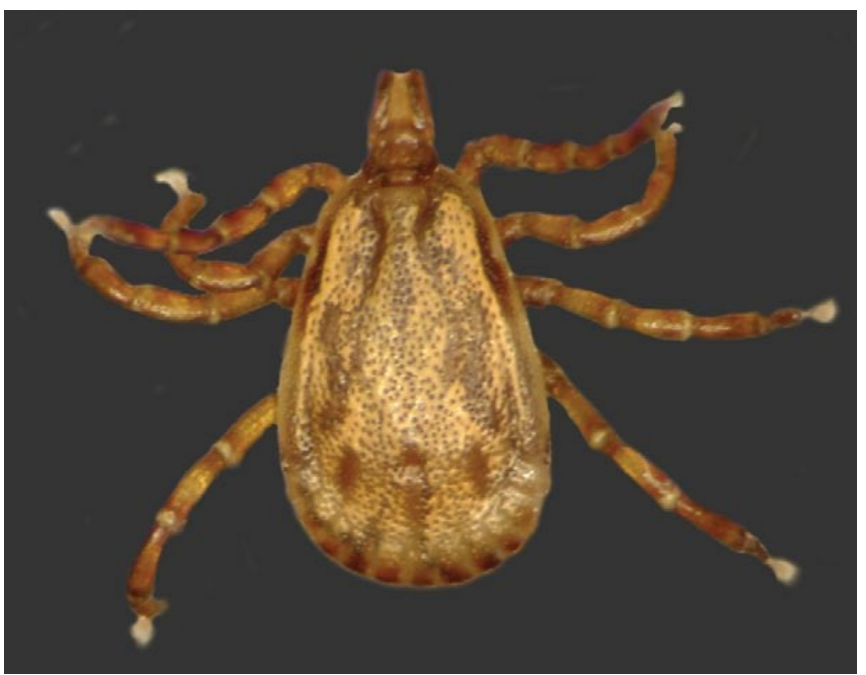

Figure 3. Specimen of A. aureolatum (male) found in Leopardus wiedii. Note the distribution of dorsal punctuations, disposition of marks over the shield, and incomplete marginal groove.

\section{Results and Discussion}

A male specimen of $A$. aureolatum was collected in L. wiedii. The margay (Figures 1 and 2) was found dead, likely hit by a car, on RS 020 road, located in Gravataí municipality (29 47' 12.9” S and $50^{\circ} 53^{\prime} 44.1^{\prime \prime}$ W, State of Rio Grande do Sul. The identification of the tick was based on the key provided by Aragáo and Fonseca (1961a), which was updated by Onofrio et al. (2006).

The male of the species $A$. aureolatum has differential characters in its ventral region. It has two large spurs in its coxae I and the sternum finishes in a straight tip (differently than that of $A$. ovale, which is slightly curved), and a spur in its coxae IV. Its dorse has well-distributed punctuations and is of a light yellowish color with dark marks over the shield followed by a central mark that extends to the festoons and two longitudinal sides, besides the two sides with anterior origin of sinuous shape that extend from half of the shield and end at the posterior third. This species has an incomplete marginal groove (Figure 3 ). A. aureolatum has been found in periurban and rural areas and more frequently in domestic dogs.

The increase of reports about $A$. aureolatum parasitism in Southern Brazil deserves attention, since this tick may have impact on public health due to its ability to transmit tick-borne pathogens, namely bacteria of Rickettsia genus (PINTER et al., 2004). It is important to note that this specimen of $A$. aureolatum was found parasitizing a margay in a very anthropized rural area, characterized by small farms with a high canine and feline population.

This study is the first report of this species in L. wiedii in the Rio Grande do Sul State.

\section{References}

ARAGÃO, H. B.; FONSECA, F. Notas de ixodologia. VIII. Lista e chave para os representantes da fauna ixodológica brasileira. Memórias do Instituto Oswaldo Cruz, v. 59, n. 2, p. 115-129, 1961a.

ARAGÃO, H. B.; FONSECA, F. Notas de ixodologia. IX. O complexo ovale do gênero Amblyomma. Memórias do Instituto Oswaldo Cruz, v. 59, n. 2, p. 131-148, 1961 b.

BARKER, S. C.; MURRELL, A. Systematics and evolution of ticks with a list of valid genus and species names. Parasitology, v. 129 (Suppl.), p. S15-S36, 2004.

EVANS, D. E.; MARTINS, J. R.; GUGLIELMONE, A. A. A review of the ticks (Acari, Ixodida) of Brazil, Their Hosts and Geographic Distribution -1. The State of Rio Grande do Sul, Southern Brazil. Memórias do Instituto Oswaldo Cruz, v. 95, n. 4, p. 453-470, 2000.

FONSECA, G. A. B. et al. Lista anotada dos mamíferos do Brasil, n. 4. Belo Horizonte: Conservation International \& Fundação Biodiversitas, 1996. $38 \mathrm{p}$.

GUGLIELMONE, A. A. et al. Amblyomma aureolatum (Pallas, 1772) and Amblyomma ovale Koch, 1844: DNA sequence, hosts and distributions. Veterinary Parasitology, v. 113, n. 3-4, p. 273-288, 2003.

GUGLIELMONE, A. A. et al. Comments on controversial tick (Acari: Ixodida) species names and species described or resurrected from 2003 to 2008. Experimental and Applied Acarology, v. 48, n. 4, p. 311-327, 2009. 
INDRUSIAK, C.; EIZIRIK, E. Carnívoros. In: FONTANA, C. S.; BENCKE, G. A.; REIS, R. E. (Orgs.). Livro vermelho da fauna ameaçada de extinçáo no Rio Grande do Sul. Porto Alegre: EDIPUCRS, 2003. p. 507-534.

LABRUNA, M. B. et al. Ticks (Acari:Ixodida) on wild carnivora. in Brazil. Experimental and Applied Acarology, v. 36, n. 1-2, p. 149-163, 2005.
ONOFRIO, V. C. et al. Família Ixodidae: características gerais, comentários e chave para gêneros. In: BARROS-BATTESTI, D. M. ARZUA, M.; BECHARA G. H. Carrapatos de Importância MédicoVeterinária da Regiáo Neotropical. São Paulo: Vox/ICTTD-3/ Butantan, 2006. p. 29-39.

PINTER, A. et al. Study of the seasonal dynamics, life cycle, and host specifity of Amblyomma aureolatum (Acari:Ixodidae), EUA. Journal of Medical Entomology, v. 41, n. 3, p. 324-332, 2004. 